\title{
THE MEASUREMENT OF TOTAL BODY WATER IN THE HUMAN SUBJECT BY DEUTERIUM OXIDE DILUTION
}

\author{
WITH A CONSIDERATION OF THE DYNAMICS OF DEUTERIUM DISTRIBUTION ${ }^{1}$
}

\author{
By PAUL R. SCHLOERB, ${ }^{2}$ BENT J. FRIIS-HANSEN, ${ }^{3}$ ISIDORE S. EDELMAN, \\ A. K. SOLOMON, ${ }^{\mathrm{s}}$ AND FRANCIS D. MOORE' \\ (From the Surgical Research Laboratories of the Peter Bent Brigham Hospital, and the \\ Department of Surgery and the Biophysical Laboratory of the Harvard \\ Medical School, Boston)
}

(Submitted for publication March 20, 1950; accepted, June 26, 1950)

\section{INTRODUCTION}

The interpretation of fluctuations in body weight and changes in the state of hydration requires a knowledge of the total amount of water in the organism. This investigation has been directed towards the perfection of a method for measurement of the total body water in the human subject.

The increasing availability and lowered cost of both stable and radioactive isotopes has made possible study of the total amount of liquid and solid

1 This work was carried out with the support of the Atomic Energy Commission under a contract between the Office of Naval Research and Harvard University and directly by the Atomic Energy Commission under a contract with the Peter Bent Brigham Hospital. Heavy water used herein was generously provided through a grant from the American Cancer Society recommended by the Committee on Growth of the National Research Council. Support was also provided directly by the American Cancer Society through an Institutional Grant to the Harvard Medical School. Support was also generously provided by a grant from the Eugene Higgins Trust, through Harvard University and from the Massachusetts Heart Association.

2 Research Fellow in Surgery, Harvard Medical School; Assistant in Surgery, Peter Bent Brigham Hospital; formerly Atomic Energy Commission Postdoctoral Research Fellow in the Medical Sciences of the National Research Council.

Research Fellow in Surgery, Harvard Medical School ; Assistant in Surgery, Peter Bent Brigham Hospital; Fellow of the American-Scandinavian Foundation.

4 Research Fellow in Surgery, Harvard Medical School ; Assistant in Surgery, Peter Bent Brigham Hospital; formerly Atomic Energy Commission Postdoctoral Research Fellow in the Medical Sciences of the National Research Council.

- Assistant Professor of Physical Chemistry, Biophysical Laboratory, Harvard Medical School.

- Moseley Professor of Surgery, Harvard Medical School and Surgeon-in-Chief, Peter Bent Brigham Hospital. bodily constituents by isotope dilution. The general principles involved and their application to the human subject have been documented (1-4). In the present study heavy water has been employed to determine the total body water in 17 adult male subjects and 11 normal females by isotope dilution. The term "total body water" is used throughout this paper to denote the equilibrium volume of dilution of heavy water, for lack of a better term. The minor extent to which this volume may differ from the actual water content is considered in detail in a subsequent section.

The ideal substance for total body water determination should be "tracer water" which is diffusible into all the fluid compartments of the body within a short time, reaching a stable uniform equilibrium at which its concentration can be measured. It should not be selectively stored, secreted or metabolized and should be exchangeable completely with water. There should be no toxic manifestations or physiologic effects from the tracer itself.

As pointed out by Hevesy and Hofer in 1934 $(1,2)$, the stable hydrogen isotope deuterium (mass 2) should be such an ideal substance. Deuterium oxide (heavy water) forms an ideal solution with water $(5,6)$ and available evidence indicates that it is not affected selectively by any of the bodily secretory or metabolic processes in the dilute solutions used $(1,2)$. Desiccation studies in animals have established the fact that the volume of dilution of deuterium oxide corresponds closely to the total body water $(3,7,8)$. The present availability of radioactive tritium (mass 3) makes the use of this isotope promising (9), although the half-life of 12 years renders its human application potentially hazardous and its 
three-fold mass increment makes it suspect as a tracer for hydrogen.

\section{A. Previous Work; Other Methods}

Total body water has been estimated variously from $51.9 \%$ to $75 \%$ of body weight. By desiccation of cadavers, Bischoff found $58.5 \%$ (10) and Mitchell and associates (11) give a value of $67.85 \%$ in a case of congestive heart failure, while $75 \%$ was found in a stillborn infant (12). Indirect methods for body water measurement have included the use of urea, thiourea, sulfanilamide, potassium, and others (13-18) as reviewed by Pace (9) but, with the exceptions of deuterium and tritium, none is wholly satisfactory. From the relation between water and electrolyte intake and output, Lavietes and colleagues (19) calculated a body water value of $70 \%$ in the subject of a balance study. Recent studies by Soberman and co-workers (8) have used antipyrine to measure total body water. This substance is inexpensive and is measured easily with a spectrophotometer (20) but has the disadvantages that it is metabolized in significant amounts, is bound selectively by protein and equilibrates slowly with fluid accumulations. These factors may be measured; a correction may be applied; and an estimation of total body water may be achieved.

The limit of accuracy using either deuterium oxide or tritiated water has been reported to be within $10 \%$ (9). Since most pathological changes occur within the limit of $10 \%$ of body water (about 5 L.) measurement of changes in total body water incident to the ordinary acute derangements of medicine and surgery would not be clinically significant in this range of error; fatal dehydration, if rapid, could occur within the error of the method.

\section{B. Purpose and Scope of the Present Study}

Our first objective has been to study a number of normal subjects in order to obtain a valid figure for total body water in a homogeneous group of healthy young adults.

Our second purpose has been to correlate total body water with other metabolic and anthropometric indices, including total exchangeable potassium, using $\mathrm{K}^{\mathbf{4 2}}$, thiocyanate phase, plasma volume, surface area and body weight. A detailed description of methods used for physical and metabolic measurements is given elsewhere (21).

Thirdly, we have observed the deuterium equilibration time, equilibrium curve, and the biological half-life of deuterium in the human, as observations ancillary to its equilibrium volume of dilution. An interpretation of the significance of these results in body water metabolism is offered.

To accomplish the above three objectives we have used a technique for the injection and measurement of $\mathrm{D}_{2} \mathrm{O}$ which is sufficiently accurate to give us clinically significant information. The accuracy of the densimetric method used for $\mathrm{D}_{2} \mathrm{O}$ analysis is defined both by repetition and by comparison using a second measurement technique, in this case the mass spectrometer. The falling drop method used herein is a modification of that proposed by Keston, Rittenberg and Schoenheimer (22) and others (23-25). It achieves a physical precision and an over-all biological accuracy which is still short of perfect but adequate for clinical interpretation. Method will be dealt with only briefly here. The exact laboratory details of purification, densimetric and spectrometric analysis are to be described separately $(26,27)$. The natural abundance of deuterium is $0.0149 \%$ (28) and is approximately the same in water and naturally occurring organic substance $(29,30)$.

\section{DETERMINATION OF TOTAL BODY WATER IN THE HUMAN}

\section{A. Materials and Methods}

1. Subjects were normal medical students, college undergraduates, and hospital personnel in good health, ranging in age from 18 to 32 years.

2. Preparation, injection and collection of deuterium oxide. Heavy water was obtained in $100 \mathrm{gm}$. ampules as $99.8 \% \mathrm{D}_{2} \mathrm{O}$ (density 1.1076 at $25^{\circ}$ C.) (31) and this amount $(90 \mathrm{cc}$.) was filtered through an ultrafine sintered glass filter before transferring, using aseptic technique, to an Erlenmeyer flask containing $0.70 \mathrm{gm}$. $\mathrm{NaCl}$. The heavy water solution was administered by pouring into an infant infusion set and by washing out the solution quantitatively with normal saline as the mixture was infused intravenously into the subject. The flask was weighed to $0.1 \mathrm{gm}$. before and after emptying.

After infusion, blood samples for total body water determinations were taken at least every 30 minutes for several hours. In some instances they were drawn more often or over a longer period in order to examine the characteristics of the early and late curves. The whole blood was allowed to clot, and the serum was separated, ampuled, and frozen at $-15^{\circ} \mathrm{C}$. until analyzed. 
3. Preparation of standards and purification of samples. Standard solutions are a limiting factor in the accuracy of the method. These solutions were made up by careful preparation of a stock solution by weighing, followed by volumetric dilution to a linear set of standards for the final measurements.

Using Pyrex glassware modified for our purposes from that originally proposed by Keston and associates, and Fetcher $(22,25)$, the serum was vacuum-distilled twice, and the condensates were collected in traps immersed in dry ice-alcohol baths. Using a manifold Pyrex closed vacuum system 12 samples may be purified simultaneously in one hour. Because of the nature of the interfering substances present, comparable precision using urine as the starting material has not as yet been obtained with the falling drop method. The mass spectrometer has been used in this study for the measurement of deuterium concentration in both urine and plasma.

4. Measurement of deuterium concentration by density. The ideal method for deuterium measurement should be adaptable to a clinical laboratory, yet should afford the accuracy which is essential to the interpretation of the results obtained. The falling drop technique, which measures the relative density, has been found to fulfill these criteria, and duplicate determinations by the mass spectrometer indicated that a comparable degree of accuracy was achieved.

The falling drop apparatus consists of a temperature bath in which the temperature is kept constant to $\pm 0.001^{\circ}$ C. by a sensitive mercury thermo-regulator and an electronic thermo-relay. Immersed in this bath, with an inner chamber surrounding it, is a graduated tube filled with orthofluorotoluene, an organic liquid which is immiscible with water and has a slightly lower density at $27^{\circ}$ C. A $22 \mathrm{cu}$. mm. drop is expressed into the top of this liquid by a fine mercury micro-pipette, and is released by raising the tip of the pipette from the surface. Measurement of the rate of fall of four drops between two graduations $15 \mathrm{~cm}$. apart is made to $0.01 \mathrm{sec}$. with electric timers. Standard solutions are measured before and after each unknown and the unknown is quantitated by interpolation.?

5. Measurement of deuterium concentration by mass spectrometer. Aliquots of samples used for the falling drop determination were ampuled and preserved at $-15^{\circ}$ C. until ready for analysis. Water was obtained from serum and urine samples by a single vacuum distillation at room temperature and was converted to $\mathbf{H}: \mathbf{H}$ (mass 2) and $H: D$ (mass 3 ) by passing the water vapor through a zinc converter at $400^{\circ} \mathrm{C}$. Each unknown was

7 Purification and analysis of the samples by the densimetric method were carried out in the Laboratories for Surgical Research of the Peter Bent Brigham Hospital ; the preparation of gaseous hydrogen and determination by the mass spectrometer were undertaken at the Biophysics Laboratory of the Harvard Medical School. The subjects were studied in the wards and laboratories of the Department of Surgery of the Harvard Medical School at the Peter Bent Brigham Hospital. run in triplicate and suitable precautions were taken to avoid "memory" and fractionation. Determination of the 3:2 mass ratio was made with a Nier type $60^{\circ}$ tube mass spectrometer. Standard solutions were prepared as described and the preparation of a calibration curve made it possible to read the deuterium concentration in "atom \%" from the graph after obtaining a 3:2 mass ratio for the unknown. "Vol. $\% \mathrm{D}_{2} \mathrm{O}$ " in excess of our determined values for natural abundance 8 ( 0.015 atom \%) is calculated from "atom \% D" excess as follows:

$$
\text { vol. } \% \mathrm{D}_{2} \mathrm{O}=\frac{100}{0.004+\frac{0.996}{\mathrm{~A}}}
$$

where:

$$
A=\frac{\text { atom } \% D-0.0150}{100}
$$

Details of the mass spectrometric method form the subject of a separate presentation (27).

6. Calculation of total body water. The isotope dilution principle was used to calculate total body water according to the equation:

$$
\mathrm{V}_{2}=\frac{\mathrm{C}_{1} \mathrm{~V}_{1}-\mathrm{C}_{\mathrm{u}} \mathrm{V}_{\mathrm{u}}}{\mathrm{C}_{2}}
$$

where: $C_{1}=$ Concentration of the injected $\mathrm{D}_{2} \mathrm{O}$.

$\mathrm{V}_{1}=$ Volume of $\mathrm{D}_{2} \mathrm{O}$ injected, corrected to $37^{\circ} \mathrm{C}$.

$C_{u}=$ Concentration of $\mathrm{D}_{2} \mathrm{O}$ in water excreted prior to equilibrium.

$V_{u}=$ Volume of excreted water prior to equilibrium.

$\mathrm{C}_{2}=$ Serum $\mathrm{D}_{2} \mathrm{O}$ concentration at equilibrium.

$\mathrm{V}_{2}=$ Volume of water into which injected $\mathrm{D}_{2} \mathrm{O}$ diffuses at equilibrium (total body water).

A figure for excreted heavy water of $0.4 \%$ of the injected dose in the first two hours was used throughout. This includes an estimate of insensible loss plus the measured urine loss.

7. Accuracy. Since the volume of the injected $\mathrm{D}_{2} \mathrm{O}$ is small, and the dilution factor is large, it is apparent that a relatively small error either in the administration of the $\mathrm{D}_{2} \mathrm{O}$ or in the collection and analysis of the sample will introduce a large error in the final result.

The accuracy of the determination increases in proportion to the amount of $\mathrm{D}_{2} \mathrm{O}$ administered. It has been found that injection of $90 \mathrm{cc}$. gave a serum concentration of about $0.2 \%$, which was convenient to measure, provided sufficient accuracy, and was not prohibitively expensive. It is possible to use a $45 \mathrm{cc}$. dose with some sacrifice in precision.

In the average adult a change of less than $0.8 \mathrm{~L}$. of body water is not apt to be significant biologically. Serial analysis of samples with the mass spectrometer has been found to have a standard deviation of 0.0005 vol. \% at a concentration of 0.368 vol. \% (27). Using the falling drop method serial determinations at a concentration of

8 Under the operating conditions of our instrument the normal abundance of deuterium in distilled water has been found to be 0.0150 atom $\%$. 


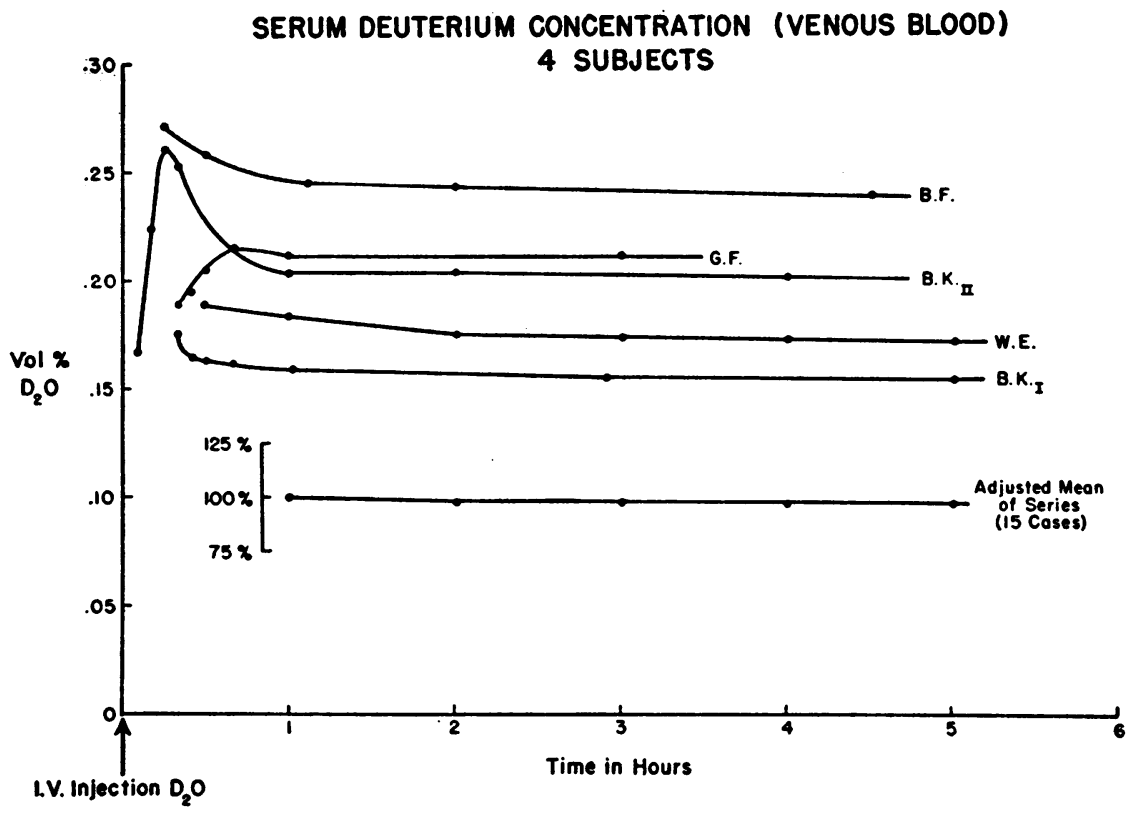

Fig. 1. Presenting the Changing Venous Serum $\mathrm{D}_{2} \mathrm{O}$ Concentration as a Function of Time Following Intravenous Injection in Five Experiments

The variations in the shape of these curves prior to equilibrium may depend upon the varying rates of transfer of water as described in the text (cf. Figure 7). On the inserted scale the mean venous serum $\mathrm{D}_{2} \mathrm{O}$ concentrations of 15 subjects is plotted with the one hour sample adjusted to $100 \%$.

0.305 vol. \% have been found to have a standard deviation of 0.0012 vol. \%. These methods of analysis are accurate to within $0.5 \%$. This analytic error corresponds to a deviation of $\pm 200 \mathrm{cc}$. in the total body water of a normal adult. However, it is estimated that additional errors (injection, sampling, possible contamination, etc.) in carrying out a complete procedure result in a determination accurate to $\pm 400 \mathrm{cc}$. in an individual with a total body water of approximately $40 \mathrm{~L}$. A more complete discussion of accuracy and reproducibility is given in the papers on method $(26,27)$.

From Table $I$ it can be seen that in the six subjects in which duplicate analyses were made with the falling drop and mass spectrometer techniques total body water determinations as per cent of body weight agreed within $1.0 \%$.

\section{B. Results}

\section{Total body water}

Since serial determinations of serum heavy water concentration indicated that equilibrium had been obtained in two hours, this two hour value was used to calculate the volume of dilution of the injected heavy water (Figure 1). In 17 normal adult males (Table $I$ ) the mean total body water was $44.2 \pm 2.8 \mathrm{~L}$. and body water as $\%$ of body weight was $61.8 \pm 3.5 \%$. In 11 nor- mal adult females (Table I) a mean total body water of $30.0 \pm 3.1 \mathrm{~L}$. or $51.9 \pm 4.7 \%$ of body weight was obtained. ${ }^{\circ}$

Pace and Rathbun (32) showed in guinea pigs that body water and electrolyte content bear a constant relationship to fat-free tissue or lean body mass. If this constant composition of lean body mass is applied to the human (33), calculation of lean body mass and body fat from total body water is possible by means of the formula:

$$
\% \text { fat }=100-\frac{\% \mathrm{H}_{2} \mathrm{O}}{0.732} \text {. }
$$

From this expression, $\%$ fat and \% fat-free body weight may be calculated. Fat constitutes a mean of $15.6 \%$ of the body weight in the males, and $29.1 \%$ in the females.

Duplicate determinations were done on two of the subjects at approximately five month intervals. Subjects J. J. G. and B. K. each showed a loss

- The determination of the total body water in eight of these normal female subjects was carried out by $\mathrm{Mr}$. David B. Sheldon as part of his tutorial work while a Harvard medical student. 
TABLE I

Summary of total body water data in normal adults

\begin{tabular}{|c|c|c|c|c|c|c|}
\hline $\begin{array}{c}1 \\
\text { Subject }\end{array}$ & $\stackrel{2}{\text { Age }}$ & $\begin{array}{c}3 \\
\text { Weight }\end{array}$ & $\begin{array}{l}4 \\
\text { Surface } \\
\text { area }\end{array}$ & \multicolumn{2}{|c|}{$\begin{array}{c}5 \text { and } 6 \\
\text { Total body water }\end{array}$} & $\frac{\begin{array}{c}\text { B } \\
\text { Body water/ } \\
\text { surface area }\end{array}}{L / M^{2}}$ \\
\hline $\begin{array}{l}\text { Males } \\
\text { L. K. } \\
\text { M. S. } \\
\text { G. K. } \\
\text { H. M. } \\
\text { A. W. } \\
\text { G. F. } \\
\text { J. E. G. } \\
\text { J. J. G. I } \\
\text { J. J. G. II } \\
\text { D. H. } \\
\text { B. K. I } \\
\text { B. K. II } \\
\text { L. L. } \\
\text { W. E. } \\
\text { R. F. } \\
\text { M. C. } \\
\text { R. C. } \\
\text { P. S. } \\
\text { J. O. }\end{array}$ & $\begin{array}{l}\text { yrs. } \\
21 \\
22 \\
25 \\
22 \\
29 \\
22 \\
29 \\
28 \\
28 \\
22 \\
32 \\
32 \\
27 \\
22 \\
27 \\
18 \\
23 \\
29 \\
25\end{array}$ & $\begin{array}{r}k g . \\
70.0 \\
64.4 \\
68.0 \\
65.5 \\
70.2 \\
68.1 \\
77.4 \\
76.7 \\
73.0 \\
81.9 \\
65.6 \\
63.1 \\
74.7 \\
65.5 \\
75.5 \\
73.4 \\
84.8 \\
65.4 \\
81.9\end{array}$ & $\begin{array}{l}M^{2} \\
1.86 \\
1.79 \\
1.80 \\
1.75 \\
1.85 \\
1.81 \\
1.89 \\
1.92 \\
1.89 \\
2.06 \\
1.78 \\
1.75 \\
1.86 \\
1.84 \\
1.95 \\
1.91 \\
2.01 \\
1.85 \\
2.08\end{array}$ & \begin{tabular}{l}
\multicolumn{1}{c}{$L$} \\
45.1 \\
$39.9(39.9)$ \\
$41.8(42.6)$ \\
43.3 \\
43.8 \\
40.6 \\
$49.3(49.0)$ \\
$46.9(46.7)$ \\
44.5 \\
$45.8(46.4)$ \\
$42.4(42.6)$ \\
40.0 \\
42.3 \\
46.0 \\
44.6 \\
44.0 \\
48.3 \\
43.8 \\
48.0
\end{tabular} & $\begin{array}{l}\text { \% body weight } \\
64.4 \\
62.0(62.0) \\
61.5(62.6) \\
66.1 \\
62.4 \\
59.6 \\
63.7(63.3) \\
61.1(60.9) \\
61.0 \\
55.9(56.7) \\
64.6(65.0) \\
63.4 \\
56.6 \\
70.2 \\
59.1 \\
59.9 \\
57.0 \\
67.0 \\
58.6\end{array}$ & $\begin{array}{l}L / M^{2} \\
24.2 \\
22.3 \\
23.2 \\
24.7 \\
23.7 \\
22.4 \\
26.1 \\
24.4 \\
23.5 \\
22.2 \\
23.8 \\
22.9 \\
22.7 \\
25.0 \\
22.9 \\
23.0 \\
24.0 \\
23.7 \\
23.1\end{array}$ \\
\hline \multicolumn{2}{|c|}{$\begin{array}{l}\text { Mean: } \\
\text { Coefficient of variation: }\end{array}$} & $\begin{array}{l}71.8 \\
9.2 \%\end{array}$ & $\begin{array}{l}1.88 \\
4.8 \%\end{array}$ & $\begin{array}{l}44.2 \\
6.7 \%\end{array}$ & $\begin{array}{l}61.8 \\
6.0 \%\end{array}$ & $\begin{array}{l}23.6 \\
4.4 \%\end{array}$ \\
\hline $\begin{array}{l}\text { Females } \\
\text { E. H. } \\
\text { B. F. } \\
\text { M. B. } \\
\text { J. L. } \\
\text { M. R. } \\
\text { M. H. } \\
\text { D. S. } \\
\text { M. A. H. } \\
\text { N. K. } \\
\text { L. K. } \\
\text { J. J. }\end{array}$ & $\begin{array}{l}27 \\
27 \\
20 \\
21 \\
23 \\
26 \\
27 \\
22 \\
23 \\
31 \\
25\end{array}$ & $\begin{array}{l}72.2 \\
60.8 \\
66.2 \\
49.3 \\
45.6 \\
58.3 \\
60.0 \\
53.8 \\
68.6 \\
60.1 \\
45.6\end{array}$ & $\begin{array}{l}1.84 \\
1.72 \\
1.80 \\
1.46 \\
1.48 \\
1.65 \\
1.62 \\
1.61 \\
1.79 \\
1.56 \\
1.47\end{array}$ & $\begin{array}{l}32.9 \\
31.7 \\
36.0 \\
25.7 \\
27.3 \\
28.1 \\
30.2 \\
29.6 \\
32.6 \\
28.8 \\
26.6\end{array}$ & $\begin{array}{l}45.6 \\
52.1 \\
54.4 \\
52.1 \\
59.9 \\
48.2 \\
50.3 \\
55.0 \\
47.5 \\
47.9 \\
58.4\end{array}$ & $\begin{array}{l}17.9 \\
18.4 \\
20.0 \\
17.6 \\
18.4 \\
17.0 \\
18.6 \\
18.4 \\
18.2 \\
18.5 \\
18.1\end{array}$ \\
\hline \multicolumn{2}{|c|}{$\begin{array}{l}\text { Mean: } \\
\text { Coefficient of variation: }\end{array}$} & $\begin{array}{l}58.2 \\
15.3 \%\end{array}$ & $\begin{array}{l}1.64 \\
8.5 \%\end{array}$ & $\begin{array}{l}30.0 \\
10.3 \%\end{array}$ & $\begin{array}{l}51.9 \\
9.1 \%\end{array}$ & $\begin{array}{l}18.3 \\
4.4 \%\end{array}$ \\
\hline
\end{tabular}

Note: Figures in parenthesis indicate the values for total body water as determined with the mass spectrometer. All other values are based on falling drop analyses.

of $2.4 \mathrm{~L}$. with weight losses of $3.7 \mathrm{~kg}$. and $2.5 \mathrm{~kg}$, respectively.

By deuterium dilution, Hevesy and Hofer in 1934. (1) found a value of $63 \%$ in man and Pace and co-workers (9), using tritium, found $62.2 \%$ of body weight in a single experiment. Moore (3) gives a value of $72.5 \%$ by deuterium dilution, also in a single human, and a figure of $65.7 \%$ in rabbits, using a gradient tube for density measurements. The antipyrine method (8) gives a mean value of $54.5 \%$ in six normal male subjects with a corresponding figure, determined by deuterium dilution in the same subjects, of $55.7 \%$, a somewhat lower result than was obtained in our male series. Hollander and co-workers (34) found $54.9 \%$ in two normal male individuals.

\section{Correlations}

In 16 of our male subjects and in six of our female subjects we have performed simultaneous measurements of thiocyanate volume, plasma volume and basal oxygen consumption, in addition to noting body weight and surface area. Our aim has been to find a consistent frame of reference for total body water.

a. Body weight and surface area. From Table $I$ it can be seen that there is a $4.4 \%$ coefficient of variation for total body water per square meter 
of surface area as compared to $6.0 \%$ for body water per kilogram of body weight in males. Similarly in females (Table I) there is a $4.4 \%$ coefficient of variation for total body water per square meter of surface area as compared to $9.1 \%$ for body water per kilogram of body weight. This is not surprising in view of the lesser contribution of increasing amounts of body fat to surface area than to body weight. A mean of 23.6 and $18.3 \mathrm{~L}$. per square meter of surface area was obtained in the male and female groups, respectively (Table I).

$b$. Phase volumes and oxygen consumption. Table II lists the correlation data for thiocyanate and plasma volumes, as well as basal oxygen consumption. There are too few determinations of simultaneous Evans blue dye dilution to derive any statistical information. Even in these small groups, however, there is marked variation in body water per liter of plasma volume.

The extracellular phase was approximated by the sodium thiocyanate method. The average value was $24.4 \%$ of body weight which is probably larger than the true extracellular phase by about $5 \%$. The thiocyanate volume gives the poorest correlation with a coefficient of variation of $11.0 \%$ (Table II). Since the thiocyanate dilution only approximates the extracellular fluid volume, it remains to be determined whether total body water bears a constant relation to this compartment. Intracellular water was estimated by the

TABLE II

Correlation of total body water with phase volumes and oxygen consumption in normal adults

\begin{tabular}{|c|c|c|c|c|c|c|c|}
\hline $\begin{array}{c}1 \\
\text { Subject }\end{array}$ & $\stackrel{2}{\substack{\text { Total body } \\
\text { water }}}$ & $\begin{array}{c}3 \\
\mathrm{SCN} \text { vol. }\end{array}$ & $\begin{array}{c}\text { Body } \\
\text { water/SCN } \\
\text { vol. }\end{array}$ & $\begin{array}{c}5 \\
\text { Plasma vol. }\end{array}$ & $\begin{array}{c}\text { B } \\
\text { Body } \\
\text { water/L } \\
\text { plasma }\end{array}$ & $\begin{array}{c}7 \\
\text { Oxygen } \\
\text { consumption }\end{array}$ & $\begin{array}{l}\mathbf{8} \\
\text { Body water } / L \\
\text { oxygen } \\
\text { consumption }\end{array}$ \\
\hline $\begin{array}{l}\text { Males } \\
\text { L. K. } \\
\text { M.S. } \\
\text { G. K. } \\
\text { H. M. } \\
\text { A. W. } \\
\text { G. F. } \\
\text { J. E. G. } \\
\text { J. J.G. I } \\
\text { D. H. } \\
\text { B. K. I } \\
\text { L. L. } \\
\text { W. E. } \\
\text { R. F. } \\
\text { M. C. } \\
\text { P.S. } \\
\text { J. O. }\end{array}$ & $\begin{array}{r}L \\
45.1 \\
39.9 \\
41.8 \\
43.3 \\
43.8 \\
40.6 \\
49.3 \\
46.9 \\
45.8 \\
42.4 \\
42.3 \\
46.0 \\
44.6 \\
44.0 \\
43.8 \\
48.0\end{array}$ & $\begin{array}{r}L \\
18.7 \\
14.6 \\
14.5 \\
15.8 \\
16.8 \\
14.9 \\
18.9 \\
22.4 \\
17.7 \\
18.4 \\
16.5 \\
15.0 \\
18.3 \\
18.3 \\
19.6 \\
20.2\end{array}$ & $\begin{array}{c}L / L \\
2.41 \\
2.73 \\
2.88 \\
2.74 \\
2.61 \\
2.72 \\
2.61 \\
2.09 \\
2.59 \\
2.30 \\
2.56 \\
3.07 \\
2.44 \\
2.40 \\
2.23 \\
2.38\end{array}$ & $\begin{array}{c}L \\
4.33 \\
2.58^{*} \\
\\
2.77^{*} \\
2.49^{*} \\
3.16^{*} \\
\\
3.53^{*} \\
3.66^{*} \\
3.26^{*} \\
3.60^{*} \\
3.70^{*} \\
3.50 \\
3.33\end{array}$ & $\begin{array}{l}L / L \\
10.4 \\
15.5 \\
\\
15.8 \\
16.3 \\
15.6 \\
\\
\\
12.0 \\
11.6 \\
14.1 \\
12.4 \\
11.9 \\
12.5 \\
14.4\end{array}$ & $\begin{array}{c}L / H r . \\
13.9 \\
12.6 \\
13.4 \\
13.2 \\
13.3 \\
\\
14.6 \\
14.0 \\
13.1 \\
12.8\end{array}$ & $\begin{array}{c}L / L / H r . \\
3.24 \\
3.17 \\
3.12 \\
3.32 \\
3.05 \\
\\
3.14 \\
3.03 \\
3.23 \\
3.59\end{array}$ \\
\hline $\begin{array}{l}\text { Mean: } \\
\text { Coefficient of } \\
\text { variation: }\end{array}$ & $\begin{array}{l}44.2 \\
6.7 \%\end{array}$ & $\begin{array}{l}17.5 \\
12.9 \%\end{array}$ & $\begin{array}{l}2.55 \\
11.0 \%\end{array}$ & 3.33 & 13.5 & 13.4 & $\begin{array}{l}3.21 \\
5.9 \%\end{array}$ \\
\hline $\begin{array}{l}\text { Females } \\
\text { E. H. } \\
\text { B. F. } \\
\text { M. B. } \\
\text { J. L. } \\
\text { M. R. } \\
\text { M. H. } \\
\text { D. S. } \\
\text { M. A. H. } \\
\text { N. K. } \\
\text { L. K. } \\
\text { J. J. }\end{array}$ & $\begin{array}{l}32.9 \\
31.7 \\
36.0 \\
25.7 \\
27.3 \\
28.1 \\
30.2 \\
29.6 \\
32.6 \\
28.8 \\
26.6\end{array}$ & $\begin{array}{r}9.7 \\
9.7 \\
12.2 \\
13.2 \\
11.6 \\
13.9 \\
10.5\end{array}$ & $\begin{array}{l}2.65 \\
2.81 \\
2.30 \\
2.29 \\
2.55 \\
2.07 \\
2.53\end{array}$ & $\begin{array}{l}1.8 \\
2.4 \\
2.3 \\
2.4 \\
2.4 \\
2.1\end{array}$ & $\begin{array}{l}14.3 \\
11.4 \\
12.2 \\
12.3 \\
12.0 \\
12.7\end{array}$ & $\begin{array}{l}13.8 \\
10.8 \\
10.1 \\
12.1 \\
11.9 \\
11.4 \\
11.9 \\
10.7 \\
10.5\end{array}$ & $\begin{array}{l}2.30 \\
2.38 \\
2.70 \\
2.32 \\
2.54 \\
2.60 \\
2.74 \\
2.69 \\
2.53\end{array}$ \\
\hline $\begin{array}{l}\text { Mean: } \\
\text { Coefficient of } \\
\text { variation: }\end{array}$ & $\begin{array}{l}30.0 \\
10.3 \%\end{array}$ & 11.5 & 2.45 & 2.2 & 12.5 & 11.5 & $\begin{array}{l}2.53 \\
6.6 \%\end{array}$ \\
\hline
\end{tabular}

* A time interval of one week to four months elapsed between the determination of total body water and plasma volume in these cases. 
difference between the total body water and the thiocyanate volume; hence it is subject to the errors of these two measurements.

Body water, expressed as liters per liter of oxygen consumed per hour, has a coefficient of variation of $5.9 \%$ in the male group and $6.6 \%$ in the female group. This fairly close correlation may be another indication of the constancy of the relation between total body water and lean body mass.

\section{EXAMINATION OF UNDERLYING PRINCIPLES}

\section{A. Deuterium Oxide as a Water Tracer}

That heavy water in dilute solutions represents a suitable tracer substance for water in the animal and human body might be expected from the fact that $\mathrm{D}_{2} \mathrm{O}-\mathrm{H}_{2} \mathrm{O}$ forms an ideal $(5,6)$ solution. More credence is lent to this concept by the fact that there is no selective renal excretion of deuterium oxide, since blood and urine concentrations have been shown to be equal (see below). When it is considered that about $120 \mathrm{cc}$. of fluid are filtered by the glomeruli each minute, and that 98-99\% of this fluid is reabsorbed by the tubules, if a selective renal effect were present due to the $\mathrm{D}: \mathrm{H}$ mass difference, the nephron would act as a fractionating column to increase the urinary concentration of deuterium; no such effect was observed. Work done thus far has given us no cause to believe that there is any fractionation in dilute solution where essentially all of the deuterium oxide exists as $\mathrm{DHO}$.

\section{B. Fate of Deuterium in the Organism}

In addition to exchange of deuterium with water to form $\mathrm{DHO}$, the $\mathrm{D}$ atoms will also exchange with the exchangeable $\mathrm{H}$ atoms of organic molecules. These are chiefly hydrogen in carboxyl, hydroxyl, amino, imino, sulfhydryl and other groups in which $\mathrm{H}$ is bound to atoms other than carbon. Hydrogen bound directly to carbon is generally stable, except when adjacent to a carboxyl group (35). Owing to these exchanges, which occur rapidly, the injected deuterium will be diluted into a volume larger than that of the body water alone, resulting in an equilibrium deuterium concentration lower than that which would be observed in the same volume of water in vitro. In order to estimate the magnitude of this factor it is necessary to consider protein, fat and carbohydrate separately, since they contain varying amounts of exchangeable hydrogen.

If it is assumed that proteins comprise $15 \%$ of body weight (36) the protein $\mathrm{H}$ atoms will then amount to approximately $0.9 \%$ of the body weight. In proteins it has been found that $5-14 \%$ of the $\mathrm{H}$ atoms are readily exchangeable $(37-39)$. The exchangeable hydrogen will, therefore, be $0.1 \%$ of the body weight, corresponding to a water volume of about $1 \%$ of body weight.

In carbohydrate about $42 \%$ of the hydrogen atoms will exchange immediately (40) but the total body carbohydrate is only $300-400$ gm., containing about $35 \mathrm{gm}$. of hydrogen, of which only $15 \mathrm{gm}$. are exchangeable, corresponding to a water volume of somewhat less than $150 \mathrm{cc}$. or about $0.2 \%$ of body weight.

The rapidly exchangeable hydrogen of fat is negligible in amount.

The above values are all based on animal or in vitro experiments. It will be appreciated, however, that the "D space" or "total exchangeable hydrogen" is about $0.5-1.5 \%$ of body weight larger than total body water. Reasoning on the basis of similar data Hevesy and Jacobsen (41) estimated the exchangeable hydrogen to have a water equivalent of $0.5-2.0 \%$ of the body weight. This is of little moment in body water measurement but is of course of great importance in considering D uptake or synthesis into organic substances. When organic substances are synthesized in the presence of heavy water, the deuterium atoms will be built into the new molecules in an amount proportional to their concentration in the body water. Since these deuterium atoms are fixed in a stable position, the amount of deuterium incorporated into such organic substances may be measured, and by appropriate means the location of the $D$ atoms in the organic molecules may be determined. These principles have been applied to the study of intermediary metabolism by Schoenheimer (36), Ussing (42), Stetten (43) and others.

\section{Toxicity of $\mathrm{D}_{2} \mathrm{O}$}

The toxicity of deuterium oxide in very high concentrations in mice was studied originally by Hansen and Rustung (44) and later by Barbour and his group (45) in this country. In our labo- 
ratory the fact was confirmed that $100 \%$ deuterium oxide is lethal to mice within a week if no other source of water is available. Development of typical central nervous system symptoms, weight loss, and an apparent terminal hypometabolic state were the characteristic features. These effects were only apparent in mice when very high concentrations of heavy water were administered, and when the serum $\mathrm{D}_{2} \mathrm{O}$ concentration in the organism reached a value of about $25 \%$. Since $100 \mathrm{gm}$. of $\mathrm{D}_{2} \mathrm{O}$ in the human produces a serum concentration of only $0.2 \%$, it is apparent that the amount used is far below the toxic level. No ill effects have been observed following $\mathrm{D}_{2} \mathrm{O}$ administration to either normal subjects or to sick patients.

THE PHENOMENA OF DEUTERIUM EQUILIBRIUM

\section{A. Equilibrium after Injection or Ingestion}

1. Equilibrium with venous blood serum. After intravenous injection, equilibration of the heavy water with body water occurred within two hours as can be seen from typical curves of the deuterium concentration in venous blood serum (Figure 1). The concentration at two hours was used to calculate the total body water and the average equilibrium time in this series was one and onehalf hours. During this equilibrium period, heavy water must mix with the blood, traverse the capillary membrane, mix with extracellular and intracellular water, exchange with free $\mathrm{H}$ groups, and reach equilibrium with water stores such as the cerebrospinal fluid and intestinal contents.

In some instances apparent equilibrium was attained much more rapidly than in others; occasionally a positive slope was observed (Figure 1). Half of the subjects reached equilibrium in one hour and all had equilibrated within two hours. In order to check the time of equilibration, the one hour value was set arbitrarily at 100 and the two and three hour values were then calculated as $98.6 \%$ and $98.2 \%$ of the one hour figure, respectively.

2. Equilibrium after oral and subcutaneous administration. In Figure 2 is shown the venous serum curve after oral ingestion and Figure 3 depicts the curve after subcutaneous injection. Due to more gradual absorption into body fluids from the subcutaneous site, equilibrium is attained with an upward slope and with less fluctuation than after oral ingestion. The equilibrium time

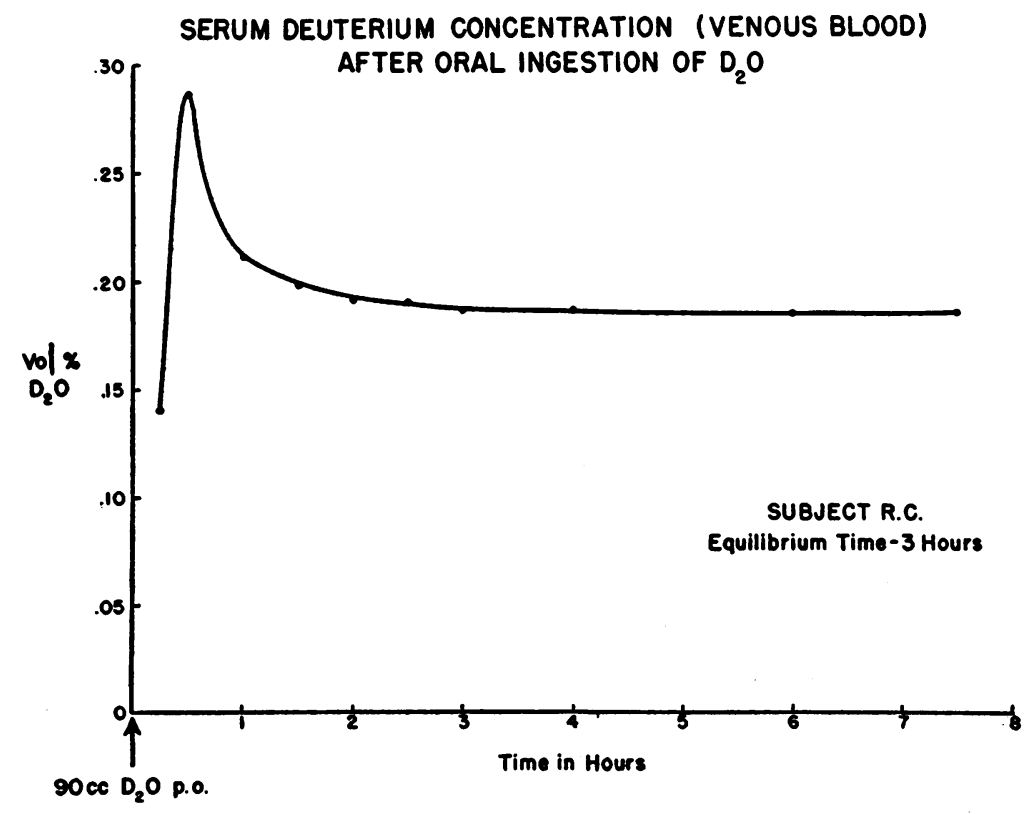

Fig. 2. Representing the Curve of Serum $\mathrm{D}_{2} \mathrm{O}$ Concentration FolLOWING THE ORAL INTAKe OF 90 cc. OF $\mathrm{D}_{2} \mathrm{O}$

The high concentration at one-half hour indicates that the rate of gastric absorption is faster than the rate of distribution of water throughout the body. 


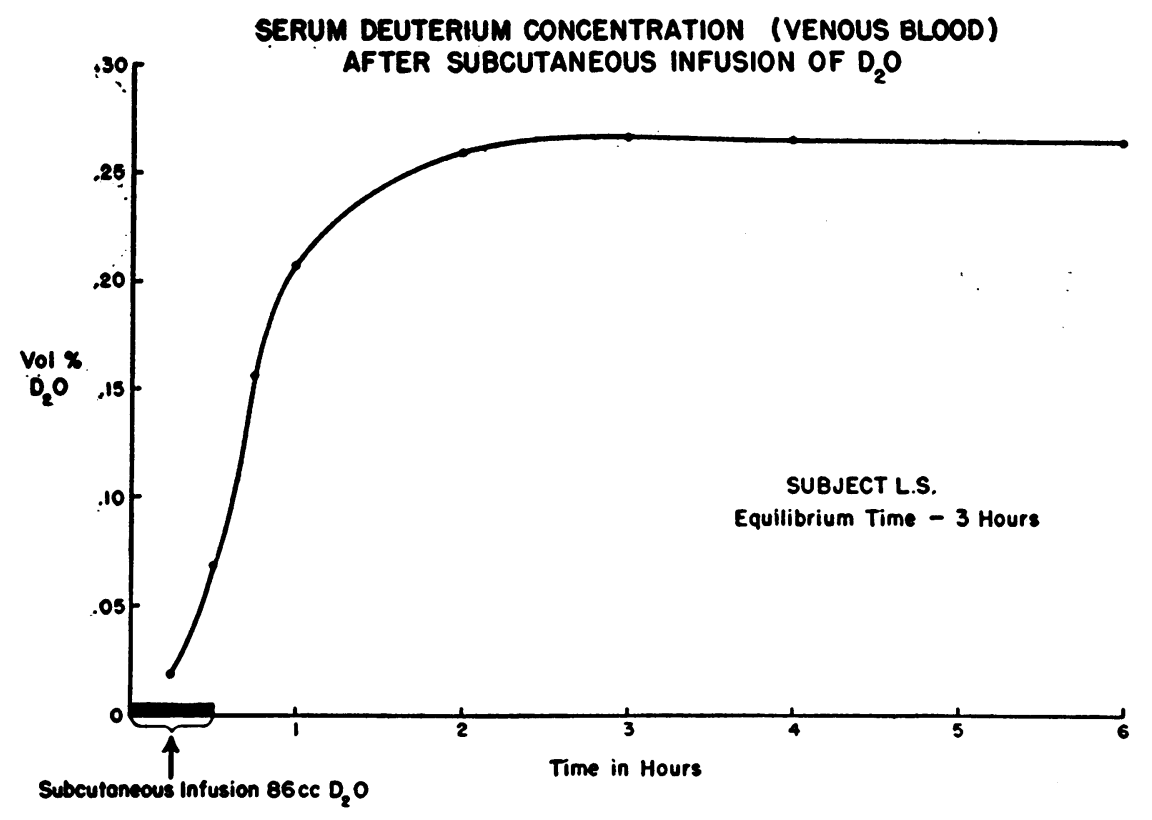

Fic. 3. Showing the Venous Serum $\mathrm{D}_{2} \mathrm{O}$ Curve Following the Subcutaneous Administration of $86 \mathrm{cc}$. OF $\mathrm{D}_{2} \mathrm{O}$

The smooth and progressive increase in concentration until equilibrium is attained indicates that the rate of distribution of $\mathrm{D}_{2} \mathrm{O}$ throughout body water is equal to or faster than the rate of absorption of $\mathrm{D}_{2} \mathrm{O}$ from the injection site.

of deuterium oxide with body fluids both after oral ingestion and subcutaneous injection is about three hours. This represents a delay of one to one and one-half hours for equilibration when compared to that which follows intravenous injection of heavy water. The time curve of heavy water concentration in serum after oral ingestion has a peak at 30 minutes. This indicates that water absorption from the gastrointestinal tract proceeds at a faster rate than the distribution of water throughout the body water. It can be inferred that with the ingestion of large amounts of water, excretion may take place before complete internal equilibrium has occurred.

3. Secretion of $D_{3} O$ in gastric juice. Gastric juice deuterium concentration was studied in two subjects. The results of one are shown in Figure 4 , which indicates a rapid equilibration in which gastric juice deuterium concentration is greater than simultaneous venous blood ten minutes after intravenous injection. It can be concluded that the rate of transfer of deuterium into the gastric juice is faster than the rate of distribution of heavy water through the limb of this subject. Ex- tension of a study such as this would make it possible to calculate the rate constant for transfer of hydrogen into the gastric juice in normal and pathologic states.

4. Secretion of $D_{2} O$ in cerebrospinal fluid. In one experiment, the concentration in the cerebrospinal fluid two and one-half hours after intravenous injection was found to be 0.209 vol. \% with a corresponding serum concentration of 0.203 vol. \%. Additional study of this transfer is in progress.

5. Plasma-urine relationships. Simultaneous determinations of deuterium concentration in plasma and urine were made with the mass spectrometer. Analyses of blood and urine after body water equilibrium had been reached showed identical values (Table III). The early urine curves showed the expected lag due to residual urine in the bladder. Deuterium was excreted in the urine at a rate of $0.1 \%$ of the administered amount per hour. Our data supports the evidence advanced by Hevesy and Hofer (1) that the deuterium oxide concentrations in serum, urine and sweat are equal after equilibrium. The absence of a 
"mass effect" in the transport of heavy water through the kidneys is additional evidence for the usefulness of deuterium oxide as a tracer for water. In studies of total body water and water turnover, urine samples can be used for deuterium oxitle analyses after equilibrium has occurred.

6. The late disappearance curve. The disappearance of $\mathrm{D}_{2} \mathrm{O}$ was studied by taking samples up to 40 days after intravenous administration. Figure 5 demonstrates a typical curve. In Figure 6 the data are plotted on a semi-log scale and prove to be linear. It follows, then, that:

$$
\frac{\mathrm{d} \ln \mathrm{C}_{\text {eq. }}}{\mathrm{dt}}=-\mathrm{K}
$$

and:

$$
\mathrm{C}_{\text {eq. }}=A \mathrm{e}^{-\mathrm{K} \mathbf{t}} \text {, }
$$

where: $\mathrm{C}_{\mathrm{eq}}$. $=$ Concentration of $\mathrm{D}_{2} \mathrm{O}$ in serum after equilibrium.

$\mathrm{K}=$ Fraction of $\mathrm{D}_{2} \mathrm{O}$ disappearing from serum per day.

A $=$ The extrapolated concentration at zero time.

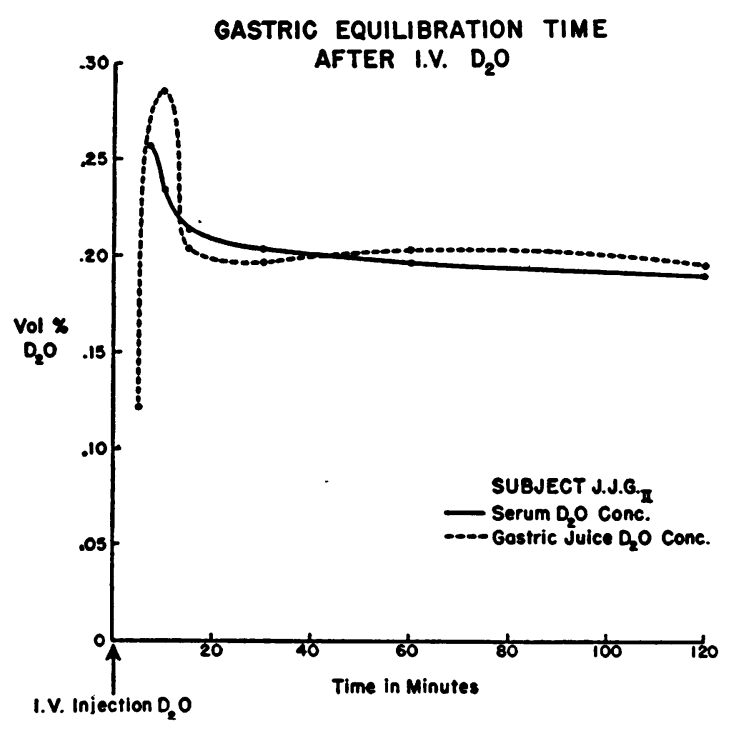

Fig. 4. Presenting the Simultaneous Time Course of the Curves of $\mathrm{D}_{2} \mathrm{O}$ Concentration in Venous Serum and Gastric Juice Following the INTravenOUS INJECTION OF $\mathrm{D}_{2} \mathrm{O}$

The shape of the gastric concentration curve with its higher peak and steeper descending limb suggests a more rapid rate of transfer of $\mathrm{D}_{2} \mathrm{O}$ into the gastric juice than into the extravascular fluid of the limb of this subject.
TABLE III

Blood and urine deuterium oxide concentrations (mass spectrometer determination)

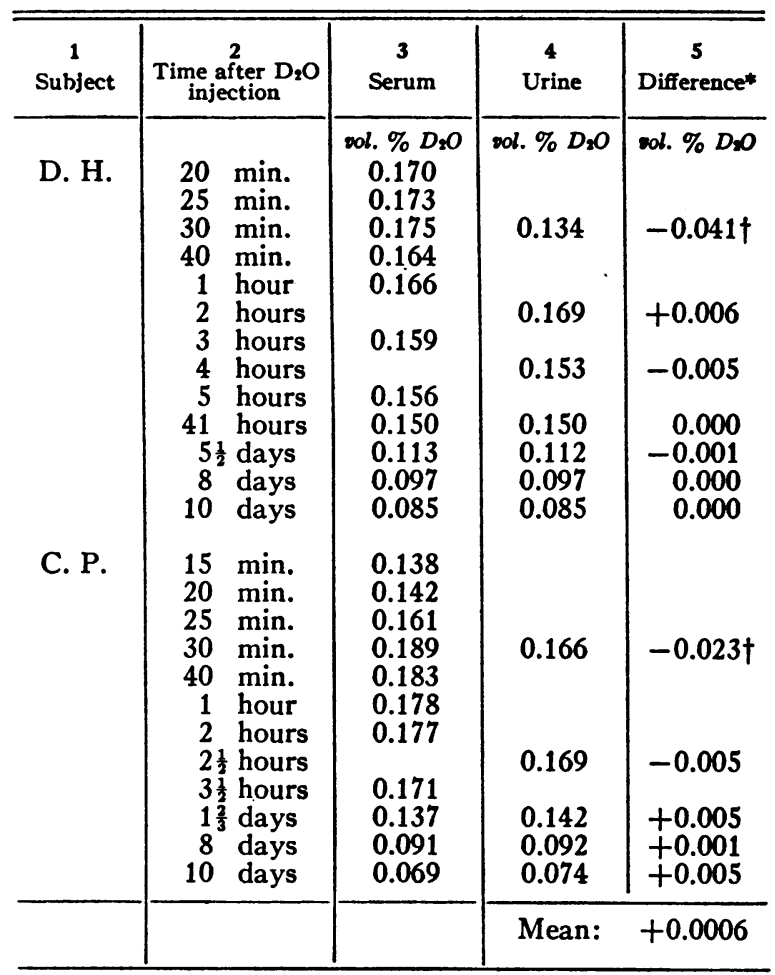

* Differences in vol. \% between simultaneous urine and plasma samples.

† These pre-equilibrium samples are omitted in calculation of the mean of the differences. Time of equilibrium for urine-serum is between two and three hours in these patients.

In patients with a constant total body water, " $\mathrm{K}$ " is the proportion of total body water exchanged per day $(46,47)$. In Table IV the values of these rate constants for water turnover have been calculated with a mean of $7.7 \%$ $( \pm 1.2 \%)$ of total body water replaced per day. In this same group the half-time for water in the body is $9.3 \pm 1.5$ days, which corresponds to an average time for an ingested water molecule in the body of $13.3 \pm 2.2$ days. This agrees well with the values of Hevesy and Hofer who studied one human subject and obtained a deuterium oxide half-time of 9.0 days and an average time for water in the body of 13.0 days. The extension of analysis of the dynamics of water replacement in sick patients should afford a means of obtaining greater insight into the pathological physiology of a wide variety of conditions in medicine and surgery. 


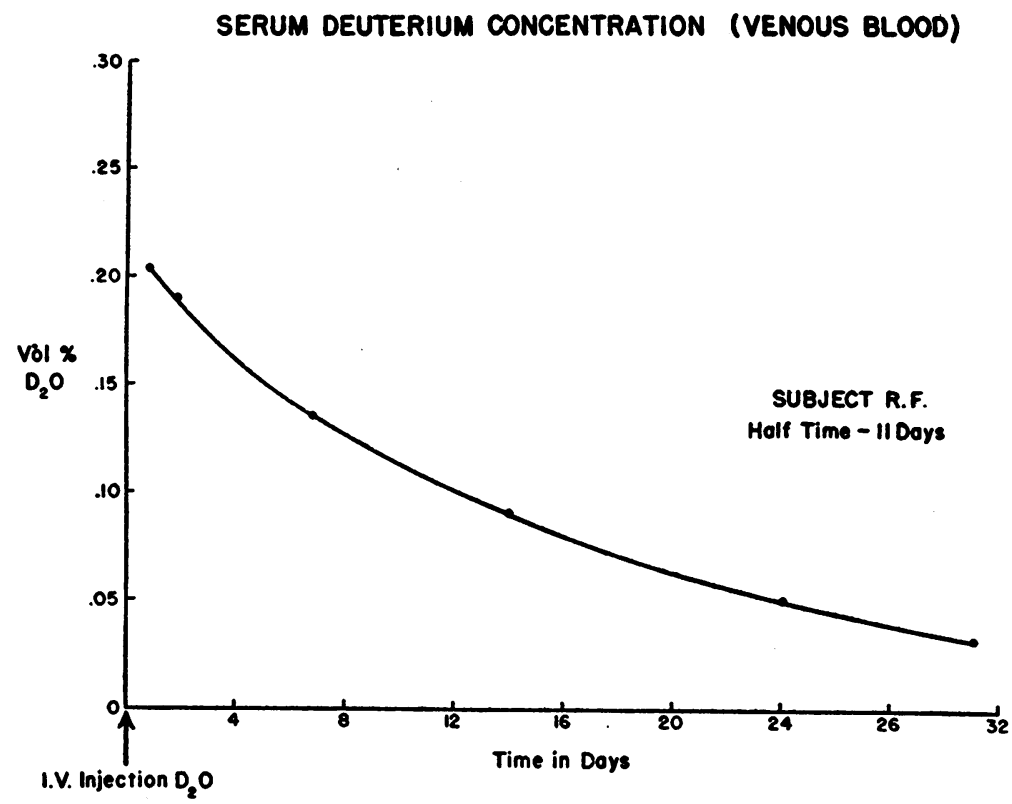

Fig. 5. Presenting the Disappearance Curve of $\mathrm{D}_{2} \mathrm{O}$ from Venous Serum in a Single Subject over a Period of 32 Days

This fall in concentration can be represented by a single exponential expression with a half time of 11.0 days (see semi-log plot, Figure 6).

\section{SERUM DEUTERIUM CONCENTRATION (VENOUS BLOOD) ON SEMI-LOG PLOT}

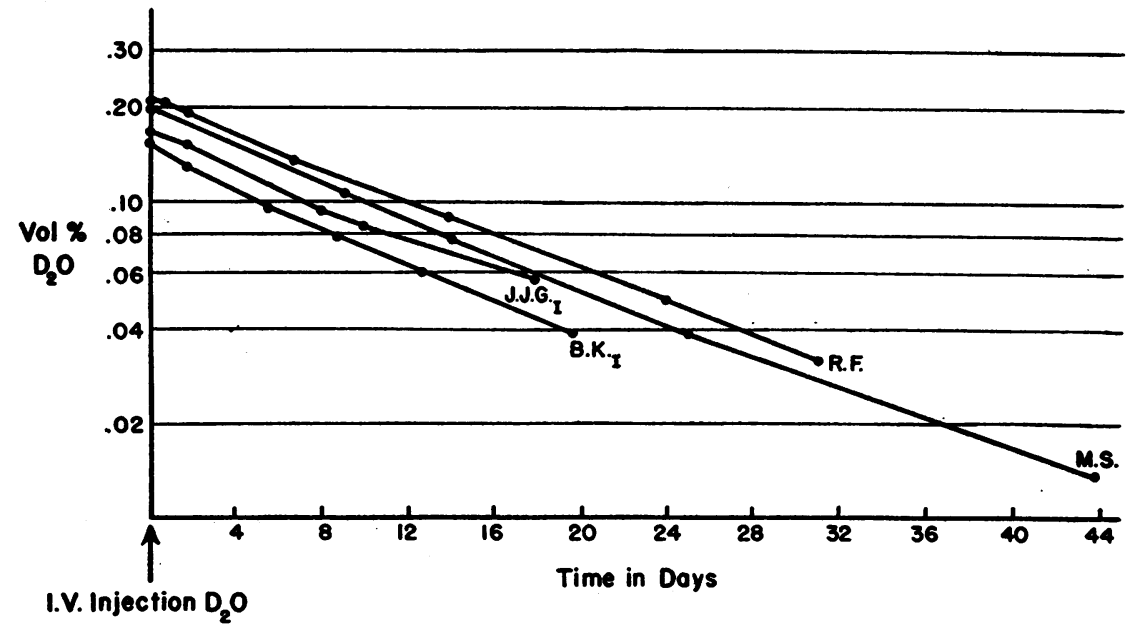

Fig. 6. Presenting a Typical Group of $\mathrm{D}_{\mathbf{2}} \mathrm{O}$ Disappearance Curves, after Equilibrium, for Periods from 18 to 44 Days

The essentially linear plot on a semi-log scale indicates that these curves can be described by a single exponential expression. 
TABLE IV

Water turnover

\begin{tabular}{|c|c|c|c|c|}
\hline $\begin{array}{c}1 \\
\text { Subjects }\end{array}$ & $\begin{array}{c}2 \\
\text { Day of final } \\
\text { determination }\end{array}$ & $\underset{\substack{\text { water } \\
\text { water }}}{\text { body }^{*}}$ & $\begin{array}{c}4 \\
\text { Half-time } \\
\text { in days }\end{array}$ & $\begin{array}{c}5 \\
\text { Average } \\
\text { timef } \\
\text { in days }\end{array}$ \\
\hline $\begin{array}{l}\text { Males } \\
\text { L. K. } \\
\text { M. S. } \\
\text { G. K. } \\
\text { H. M. } \\
\text { A. W. } \\
\text { G. F. } \\
\text { J. E. G. I } \\
\text { J. J. G. I } \\
\text { J. J. G. II } \\
\text { D. H. } \\
\text { L. L. } \\
\text { C. P. } \\
\text { W. E. } \\
\text { R. F. } \\
\text { B. K. I } \\
\text { B. K. II } \\
\text { R. C. } \\
\text { P. S. } \\
\text { Females } \\
\text { E. H. } \\
\text { B. F. } \\
\text { M. D. }\end{array}$ & $\begin{array}{r}6 \\
44 \\
12 \\
16 \\
13 \\
13 \\
13 \\
18 \\
14 \\
10 \\
15 \\
10 \\
14 \\
14 \\
30 \\
7 \\
7 \\
16\end{array}$ & $\begin{array}{l}7.0 \\
7.1 \\
6.5 \\
8.7 \\
5.8 \\
8.1 \\
9.0 \\
6.9 \\
7.3 \\
7.3 \\
9.5 \\
8.1 \\
9.0 \\
6.2 \\
7.7 \\
9.0 \\
5.3 \\
8.7 \\
1 \\
7.7 \\
8.8 \\
7.9\end{array}$ & $\begin{array}{r}9.9 \\
9.7 \\
10.6 \\
8.0 \\
12.0 \\
8.6 \\
7.7 \\
10.0 \\
9.5 \\
9.5 \\
7.3 \\
8.5 \\
7.7 \\
11.2 \\
9.0 \\
7.7 \\
13.0 \\
8.0\end{array}$ & $\begin{array}{l}14.3 \\
14.1 \\
15.4 \\
11.5 \\
17.2 \\
12.3 \\
11.1 \\
14.5 \\
13.7 \\
13.7 \\
10.5 \\
12.3 \\
11.1 \\
16.1 \\
13.0 \\
11.1 \\
18.9 \\
11.5 \\
\\
13.0 \\
11.4 \\
12.7\end{array}$ \\
\hline \multicolumn{2}{|c|}{$\begin{array}{l}\text { Mean: } \\
\text { Standard deviation: }\end{array}$} & $\begin{array}{l}7.7 \\
1.2\end{array}$ & $\begin{array}{l}9.3 \\
1.5\end{array}$ & $\begin{array}{r}13.3 \\
2.2\end{array}$ \\
\hline
\end{tabular}

$* \%$ of body water turnover/day $=\frac{\ln 2}{\text { half-time }} \times 100$

$\dagger$ Half-time obtained from a semi-logarithmic plot of serum concentration against time in days.

$\ddagger$ Average time of a water molecule in the body $=$

Fraction Body Water Turnover/Day

\section{B. Analysis of the Early Arterial Curve}

Figures 7 and 8 demonstrate an attempt to investigate details of the equilibrium factors operative between arterial and venous blood. Heavy water was injected intravenously at $t_{0}$ within 30 seconds into two veins. Subsequent femoral arterial and antecubital venous samples were taken at the times indicated by the points on the curves. The phase of rapid intravascular mixing is shown by the arterial peak at 40 seconds.

After this injection of $100 \mathrm{cc}$. of $99.8 \% \mathrm{D}_{2} \mathrm{O}$, the injection mass is carried to the lungs where it is diluted in the small extravascular phase of lung tissue. Still at high concentration, it is then transported to the left heart whence it starts its arterial journey to the body water with which it exchanges and mixes. The decreasing concentration in arterial blood under such circumstances, therefore, exhibits a character defined by the sys- tem of fluid compartments and membranes across which deuterium exchange occurs prior to equilibrium.

From these data it appears that the rate constant for distribution of water in the extremities must be appreciably slower than that for other large areas in the body. The arterial concentration remains elevated because of the continuous contribution to the right heart of high-deuterium venous blood from other (presumably visceral) areas. Studies are in progress to derive comparative data for rates of distribution of water into the various tissues and organs of the body.

In Figure 7 the arterial deuterium oxide concentration up to 60 minutes after injection is plotted on linear coordinates. In Figure 8, the same data are plotted on a semi-logarithmic scale, and by subtraction two straight lines are obtained. The general expression for the pre-equilibrium phase of the deuterium oxide curve would then be :

$$
\mathrm{C}_{\mathrm{t}}=\mathrm{Ae}^{-\lambda_{1} t}+\mathrm{Be}^{-\lambda_{2} t}+\mathrm{C}_{\text {eq. }} \text {. }
$$

where: $\quad \mathrm{C}_{t}=$ Concentration of $\mathrm{D}_{2} \mathrm{O}$ in arterial serum at time $t$.

$\mathrm{C}_{\mathrm{eq} .}=$ Concentration of $\mathrm{D}_{2} \mathrm{O}$ in arterial serum at equilibrium.

$\lambda_{1}$ and $\lambda_{2}=$ Slopes of lines as labeled in Figure 8 and are rate constants for each component - of the curve.

In this patient the equation obtained is:

$$
\mathrm{C}_{t}=0.390 \mathrm{e}^{-0.565 t}+0.234 \mathrm{e}^{-0.0727 t}+0.146 \text {. }
$$

Since there are two dominant or average rate constants which characterize the internal distribution of deuterium oxide, we can expect to have two general rate defining boundaries in the organism. The time relationships of the curve cannot be explained on the basis of a unicameral body water.

Flexner and associates $(48,49)$ presented similar curves and assumed that there were two sets of capillaries: a fast group and a slow group which determined the two rate constants. At the present time we are considering alternative hypotheses. These slopes could be explained by transfer across cell membranes as well as across capillaries. We have refrained from analyzing our data in terms of proportions of fluid diffusing 


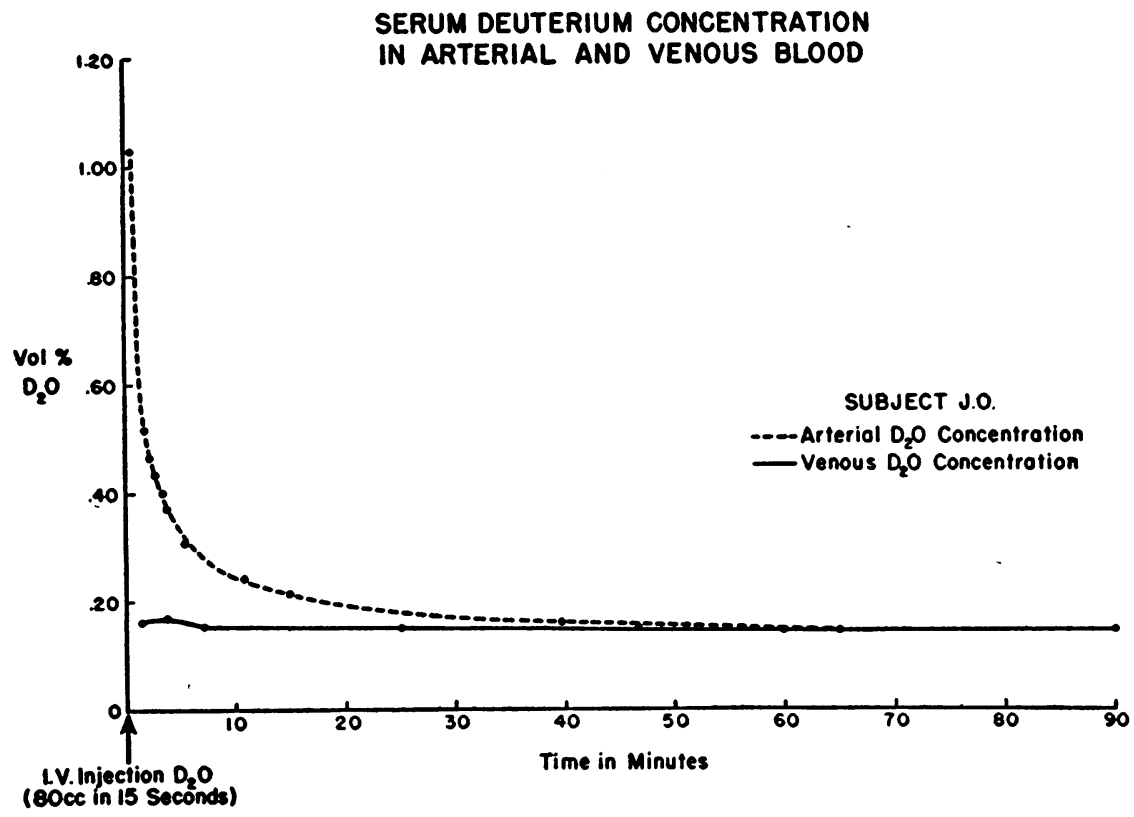

Fig. 7. Presenting Simultaneous Serum $\mathrm{D}_{2} \mathrm{O}$ Concentrations from the Femoral Artery and Antecubital Vein after Intravenous Injection of $\mathrm{D}_{2} \mathrm{O}$ in a NoRmal SUbJEct

Arterial-venous equilibrium is reached in about one hour. The difference in arterial and venous concentrations of $\mathrm{D}_{2} \mathrm{O}$ prior to equilibrium represents the net transport of $\mathrm{D}_{2} \mathrm{O}$ in the arm during this interval; differences in deuterium transfer in the limbs account for the varying early venous slopes shown in Figure 1.

\section{SERUM DEUTERIUM CONCENTRATION (ARTERIAL BLOOD) \\ ON SEMI-LOG PLOT \\ ANALYSIS OF SLOPE COMPONENTS}

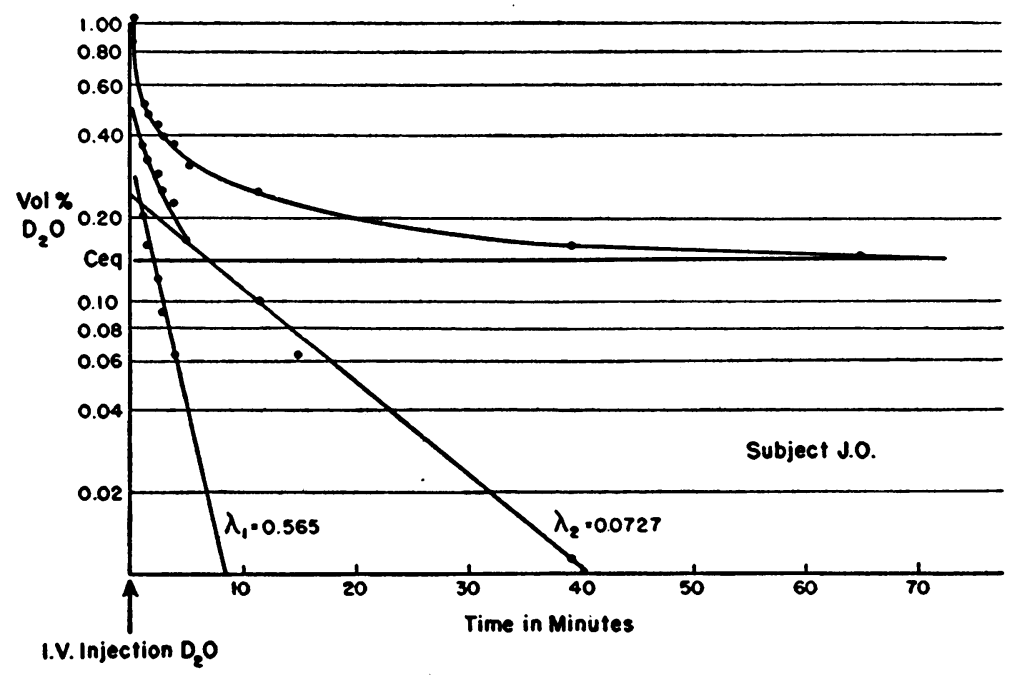

Fig. 8. Presenting the Graphic Analysis of the Arterial D,O Curve

It can be seen that the curve can be broken down into three straight line components, one of which is that of the equilibrium value (cf. Figure 6) and the other two of which have decay constants $\left(\lambda_{1}\right.$ and $\left.\lambda_{2}\right)$ as shown. 
into and out of body water areas until sufficient data are obtained to establish the nature of the rate determining boundaries for water. Such experiments now in progress will be reported separately.

\section{SUM MARY}

1. Analysis of the serum deuterium oxide concentration by a double vacuum distillation and densimetric determination with the falling drop apparatus proved to be a precise analytic procedure and checked well with duplicate determinations done on the mass spectrometer.

2. Total body water was determined by deuterium oxide dilution in 17 normal male subjects with a range of $55.9 \%$ to $70.2 \%$ and an average value of $61.8 \%$ of body weight. Eleven normal females ranged from $45.6 \%$ to $59.9 \%$ with an average of $51.9 \%$, or $9.9 \%$ less than the males. These total body water figures have a precision of \pm 800 cc. or $\pm 2 \%$ of total body water in a normal adult.

3. Of the physical indices studied, total body water was correlated most closely with surface area and oxygen consumption.

4. After intravenous injection of $\mathrm{D}_{2} \mathrm{O}$, equilibrium in body water as measured by venous blood serum is attained within two hours.

5. The dynamics of deuterium equilibrium, involving intravenous, oral and subcutaneous administration and a study of the early arteriovenous deuterium differences, is described.

6. The half-time for heavy water in the adult human body is $9.3 \pm 1.5$ days.

7. Preliminary results from the study of deuterium oxide equilibration by analysis of arterial blood samples soon after intravenous injection of heavy water consistently revealed a double exponential curve.

\section{ACKNOWLEDGMENTS}

We wish to thank Mrs. Miriam C. Levine and Mrs. Judith L. Lucas for their valuable technical assistance in carrying out these studies.

\section{BIBLIOGRAPHY}

1. Hevesy, G., and Hofer, E., Elimination of water from the human body. Nature, 1934, 134, 879.

2. Hevesy, G., and Hofer, E., Die Verweilzeit des Wassers in menschlichen Körper, untersucht mit Hiffe von "schwerem" Wasser als Indicator. Klin. Wchnschr., 1934, 13, 1524.
3. Moore, F. D., Determination of total body water and solids with isotopes. Science, 1946, 104, 157.

4. Moore, F. D., The use of isotopes in surgical research. Surg., Gynec. \& Obstet., 1948, 86, 129.

5. Swift, E., Jr., The density of $\mathrm{D}_{2} \mathrm{O}-\mathrm{H}_{2} \mathrm{O}$ mixtures at $5^{\circ}$ and $25^{\circ}$. J. Am. Chem. Soc., 1939, 61, 198.

6. Longsworth, L. G., The densities of mixtures of light and heavy water. J. Am. Chem. Soc., 1937, 59, 1483.

7. McDougall, E. J., Verzar, F., Erlenmeyer, H., and Gaertner, H., Heavy water in the animal body. Nature, 1934, 134, 1006.

8. Soberman, R., Brodie, B. B., Levy, B. B., Axelrod, J., Hollander, V., and Steele, J. M., The use of antipyrine in the measurement of total body water in man. J. Biol. Chem., 1949, 179, 31.

9. Pace, N., Kline, L., Schachman, H. K., and Harfenist, M., Studies on body composition. IV. Use of radioactive hydrogen for measurement in vivo of total body water. J. Biol. Chem., 1947, 168, 459.

10. Bischoff, E., Einige Gewichts und Trocken-Bestimmungen der Organe des menschlichen Körpers. Ztschr. f. rat. Med., 1863, 20, 75.

11. Mitchell, H. H., Hamilton, T. S., Steggerda, F. R., and Bean, H. W., The chemical composition of the adult human body and its bearing on the biochemistry of growth. J. Biol. Chem., 1945, 158, 625.

12. Iob, V., and Swanson, W. W., Mineral growth of the human fetus. Am. J. Dis. Child., 1934, 47, 302.

13. Painter, E. E., Total body water in the dog. Am. J. Physiol., 1940, 129, 744.

14. Winkler, A. W., and Smith, P. K., The apparent volume of distribution of potassium injected intravenously. J. Biol. Chem., 1938, 124, 589.

15. Chesley, L. C., Observations on absorption, apparent volume of distribution and excretion of thiourea. J. Clin. Invest., 1944, 23, 856.

16. Danowski, T. S., Use of thiourea as a measure of change in body water. J. Biol. Chem., 1944, 152, 207.

17. Marshall, E. K., Jr., Emerson, K., Jr., and Cutting, W. C., Distribution of sulfanilamide in organism. J. Pharmacol. \& Exper. Therap., 1937, 61, 196.

18. Bourdillon, J., Distribution in body fluids and excretion of ingested ammonium chloride, potassium chloride and sodium chloride. Am. J. Physiol., 1937, 120, 411.

19. Lavietes, P. H., D’Esopo, L. M., and Harrison, H. E., The water and base balance of the body. J. Clin. Invest., 1935, 14, 251.

20. Brodie, B. B., Axelrod, J., Soberman, R., and Levy, B. B., The estimation of antipyrine in biological materials. J. Biol. Chem., 1949, 179, 25.

21. Corsa, L., Jr., Olney, J. M., Jr., Steenburg, R. W., Ball, M. R., and Moore, F. D., The measurement of exchangeable potassium in man by isotope dilution. J. Clin. Invest., 1950, 29, 1280.

22. Keston, A. S., Rittenberg, D., and Schoenheimer, R., Determination of deuterium in organic compounds. J. Biol. Chem., 1937-38, 122, 227. 
23. Fenger-Eriksen, K., Krogh, A., and Ussing, H. H., A micro-method for accurate determination of $\mathrm{D}_{2} \mathrm{O}$ in water. Biochem. J., 1936, 30, 1264.

24. Cohn, M., in: Preparation and Measurement of Isotopic Tracers. J. W. Edwards, Ann Arbor, Mich., 1946, pp. 51-59.

25. Fetcher, E. S., Jr., Modifications of apparatus for deuterium oxide determination by the falling drop. Indust. \& Engin. Chem. (Analyt. Ed.), 1944, 16, 412.

26. Schloerb, P. R., Friis-Hansen, B. J., Sheldon, D. B., and Moore, F. D., The use of the falling drop method to measure deuterium oxide in body fluids. In preparation.

27. Solomon, A. K., Edelman, I. S., and Soloway, S., The use of the mass spectrometer to measure deuterium in body fluids. J. Clin. Invest., 1950, 29, 1311.

28. a. Voskuyl, R. J., The deuterium-protium ratio in natural waters. Thesis, Harvard University, 1938.

b. Greene, C. H., and Voskuyl, R. J., The deuteriumprotium ratio. I. The densities of natural waters from various sources. J. Am. Chem. Soc., 1939, 61, 1342.

29. Emeléus, H. J., James, F. W., King, A., Pearson, T. G., Purcell, R. H., and Briscoe, H. V. A., The isotopic ratio in hydrogen; a general survey by precise density comparisons upon water from various sources. J. Chem. Soc., 1934, 1207.

30. Dole, M., The concentration of deuterium in organic compounds. II. A general discussion with particular reference to benzene. J. Am. Chem. Soc., 1936, 58, 580.

31. Stokland, K., Ronaess, E., and Tronstad, L., The dilatation of heavy water. Trans. Faraday Soc., 1939, 35, 312.

32. Pace, N., and Rathbun, E. N., Studies on body composition. III. The body water and chemically combined nitrogen content in relation to fat content. J. Biol. Chem., 1945, 158, 685.

33. Messinger, W. J., and Steele, J. M., Relationship of body specific gravity to body fat and water content. Proc. Soc. Exper. Biol. \& Med., 1949, 70, 316.

34. Hollander, V., Chang, P., and Co Tui, Deuterium oxide and thiocyanate spaces in protein depletion. J. Lab. \& Clin. Med., 1949, 34, 680.

35. Schoenheimer, R., and Rittenberg, D., Deuterium as an indicator in the study of intermediary metabolism. J. Biol. Chem., 1935, 111, 163.
36. Schoenheimer, R., Dynamic State of Body Constituents. Harvard University Press, Cambridge, 1946.

37. Krogh, A., and Ussing, H. H., Exchange of hydrogen between free water and organic substances in the living organism. Skandinav. Arch. $f$. Physiol., 1936, 75, 90.

38. Ussing, H. H., Exchange of $H$ and $D$ atoms between water and protein in vivo and in vitro. Skandinav. Arch. f. Physiol., 1938, 78, 225.

39. Smith, P. K., Trace, J., and Barbour, H. G., The fate of deuterium in the mammalian body. $\mathrm{J}$. Biol. Chem., 1936, 116, 371.

40. Hamill, W. H., and Freudenberg, W., Quantitative isotopic exchange reactions in the carbohydrate group. J. Am. Chem. Soc., 1935, 57, 1427.

41. Hevesy, G., and Jacobsen, C. F., Rate of passage of water through capillary and cell walls. Acta physiol. Scandinav., 1940, 1, 11.

42. Ussing, H. H., Use of amino acids containing deuterium to follow protein production in the organism. Nature, 1938, $142,399$.

43. Stetten, DeW., Jr., and Stetten, M. R., Studies in carbohydrate metabolism. VII. The distribution of deuterium in a sample of deuterio glucose excreted by a diabetic rabbit. J. Biol. Chem., 1946, $165,147$.

44. Hansen, K., and Rustung, E., Untersuchungen über die biologischen Wirkungen von "schwerem Wasser" bei warmblütigen Tieren. Klin. Wchnschr., 1935, 14, 1489.

45. Barbour, H. G., Basis of pharmacological action of heavy water in mammals. Yale J. Biol. \& Med., 1937, 9, 551.

46. Burch, G. E., Threefoot, S. A., and Cronvich, J. A., Theoretic considerations of biologic decay rates of isotopes. J. Lab. \& Clin. Med., 1949, 34, 14.

47. Solomon, A. K., Equations for tracer. experiments. J. Clin. Invest., 1949, 28, 1297.

48. Flexner, L. B., Cowie, D. B., and Vosburgh, G. J., Studies on capillary permeability with tracer substances, in: Cold Spring Harbor Symposium on Quantitative Biology. Long Island Biological Laboratory, Cold Spring Harbor, Long Island, N. Y., 1948, 13, 88.

49. Flexner, L. B., Gellhorn, A., and Merrell, M., Studies on rates of exchange of substances between the blood and extravascular fluid. I. The exchange of water in the guinea pig. J. Biol. Chem., 1942, $144,35$. 